\title{
Audit Quality, Legal Systems, Investment Opportunity Set and Ownership Structure: Evidence From United States, France and Germany
}

\author{
Sana Masmoudi Mardessi, Abdelfettah Bouri \\ University of Sfax, Sfax, Tunisia
}

\begin{abstract}
This paper investigates the determinants of audit quality of three countries especially the United States, France and Germany belonging to three different legal systems. These determinants concern the legal system of country, investment opportunity set and ownership structure which have influence of audit quality.Empirical results show, initially, that specificities of legal system are positively associated with audit quality appreciated by size of audit firm. Then, the results reveal that investment opportunity set influences partially size of audit firm. Finally, ownership structure influences negatively the search for a high audit quality.
\end{abstract}

Keywords:audit quality, legal systems, investment opportunity set, ownership structure

\section{Introduction}

The bankruptcy of a great number of organizations during the last decade led authorities to various reflexions on the whole of bodies and rules of decisions, information and monitoring that allow to have right and partners of an institution to see their respected interests and their voices heard in the operation of company. Similar scandals seem to generate a situation of mistrust with respect to countable information and various bodies of regulations. It is undoubtedly in United States where the reaction was the strongest, not only because the first business burst in this country, but especially because the problem had become a problem of social, economic and financial nature. With the wave of these scandals, financial topicality impelled new regulations which were born in order to attenuate major sources "which made these scandals burst" and improve process of governance making it possible to protect interests from various fascinating parts. Sarbanes-Oxley (2002) in the United States and Financial Safety Law (2003) in France, to quote only these two reforms, allocated a capital share with improvement of audit quality. Accordingly, lawful framework of audit quality made many changes. Reflexions on the installation of radical reforms thus began, and led in particular to legislative evolutions that it is at the national or international level. The idea is thus to reinforce the statute of auditor like his role as a professional called to check financial information revealed by the companies with investors in order to have their confidences. The problem which was felt is to have within the companies, an allowing qualified auditor, to give a reasonable

Sana Masmoudi Mardessi, Master assistant professor, High School of Trade, University of Sfax.

Abdelfettah Bouri, professor, Faculty of Economics and Management Sciences, University of Sfax. 
insurance, which financial statements are sincere and regular and to really reduce agency conflicts which can emerge particularly between fascinating parts of company.

Audit quality was defined in countable literature as joined probability, evaluated by market, that auditor discovers an anomaly present in financial statements and reveals it. That is to say, product of two probabilities, in particular discovery of anomaly (competence) and the revelation of this anomaly knowing that it was discovered (independence) (DeAngelo, 1981). In the same way, a ratio report of audit is considered of quality if it is the result of a process of technically qualified and independent audit (Lemon \& Taffler, 1992). Many researchers adopted this double approach to define audit quality by distinguishing technical skill (quality of detection) from independence (quality of revelation) of auditor (Knapp, 1991; Flint, 1988; Moizer, 1997). The competence concept of auditors relates to the fact of having knowledge, formation, qualification and sufficient experience to conclude an audit legal (Flint, 1988). As for independence, it constitutes a significant component of audit quality, since it guarantees that work. Conclusions formulated by auditors are not sullied with subjectivity, handling or voluntary omissions following complicities with one of contracting parts within company (Manita \& Chemangui, 2007).

Focusing on audit quality, there are some researchers who identified factors which influence this quality. The importance of debate concerning these problems and installation of radical reforms led to legislative evolutions. In this paper, we show which factors that can influence audit quality?

Our study contributes to the extant literature in several ways. First, we provide contribution to the studies relating to the audit quality by studying jointly the factors of audit quality and not each factor taken separately. Second, we provide contribution to stakeholders: On the one hand, for investors, by investing their funds in audited companies by the size of audit firms and pertaining to qualified countries of strong legal protection. On the other hand, for managers, by the choice of the auditors belonging to the audit firms having a higher quality for the decision-making in the choice of the investment opportunity set.

The remainder (rest) of paper is structured as follows. Section 2 develops our research hypotheses. Section 3 explains how we measure the explanatory factors, especially, legal system of countries, investment opportunity set and ownership structure. Section 4 describes our sample and data sources, and presents the empirical models for testing hypothesis. Section 5 reports the results of our main regressions. However, section 6 reports the results of our robustness checks. The final section concludes the paper.

\section{Hypothesis Development}

This paper focuses on two theoretical currents for examining explanatory factors. These factors influence audit quality, particularly, legal approach called "law and finance” and "theory of agency".

\section{Audit Quality and Legal Systems}

Comparative legal scholars agree that, even though no two nation's laws are exactly alike, some national legal systems are sufficiently similar in certain critical respects to permit classification of national legal systems into major families of law. Based on this approach, scholars identify two broad legal traditions: civil law and common law (La Porta, Lopez-de -Silanes, \& Shleifer, 1998; La Porta, Lopez-de-Silanes, \& Shleifer, 2000). In this paper, we are going to look only at laws pertaining to investor protection, and specifically only at company and bankruptcy/reorganization laws. Company laws exist in all countries, and are concerned with: (1) The legal relations between corporate insiders (members of the corporation, i.e., shareholders, directors) and the 
corporation itself; (2) The legal relations between the corporation and certain outsiders, particularly creditors. Bankruptcy/reorganization laws apply more generally than just to companies, but deal specifically with procedures that unfold in the case of failure to pay back debts. All these laws are part of the commercial codes in countries' civil law, and exist as separate laws, mainly in the form of acts, in common law (La Porta, Lopez-de -Silanes, \& Shleifer, 1998; La Porta, Lopez-de-Silanes, \& Shleifer, 2000).

Moreover, outside investors' legal degree of protection of the insiders' expropriation granted by the regulations in the country depend on origin of legal systems, contents of rules of right and their conditions for application. Indeed, empirical results show that countries of Common Law protect better minority shareholders and creditors than countries from Civil Law. In the same way, legal system of the country, in particular Common Law is not built from the beginning to the end but rather depends on the borrowed ideas of legal traditions. These legal traditions are deducted in Civil Law and Common Law. Civil Law is deducted in German, French and Scandinavian. Also, legal protection systems of investors are generally pertaining of strong systems in countries of Common Law. They affect ownership structure and lead to more dispersed property, more minority shareholders, with an increased use of external financing and more developed financial markets. All these elements result in other things creating potential problems of agencies, which are born in countries with strong legal protection system from investors and are solved through a strong government of company, a better quality of audit which provides a credible base in order to reduce asymmetry of information between companies and outside investors.

Francis, Khurana and Pereira (2003) show that countries of Common Law offer a better protection of investors. They have more developed financial markets, dispersed property of capital, transparent accountancy, high audit quality and stockholders' equity which are more significant than countries of Civil Law. These authors also reveal that a high quality of national countable standards and the application of these standards by means of one to that credible constitute principal resultant of protection systems of investors who lead to the development of high audit quality and accountancy. Particularly, high audit quality plays a paramount role in government of company when it has a significant property of outsiders. The latter is in the countries with strong legal protection systems of investors, leading to more problems of asymmetries of information between outsiders and insiders.

Since accountancy becomes fundamental in government of company, the need for audit is also fundamental like a mechanism of application in the checking of countable information (Watts \& Zimmerman, 1986;Hung, 2000). Thus, the need to resort to audit quality also emerges from owing to the fact that accountancy of engagement allows a considerable managerial discretion which can lead to opportunist handling of countable figures. Therefore, the first role of audit is to delimit such opportunist behaviours and to make accountancy reliable for conclusion of the contracts with outsiders (Francis, Maydew, \& Sparks, 1999; Hung, 2000).

In the same way, the study of Kim et al. (2003) shows that audit firms pertaining to Big 5 are different from the other audit firms by their prudent attitude with respect to countable choices, and probably because of the pressure which was exerted on them by the American legal apparatus. In other words, the audit firm pertaining to Big 5 would tolerate less handling aiming at overestimating the result because they extremely risk to be prosecuted by groups of investors and to be condemned to payment of significant damages. This differentiation in international wide-area networks is however less probable in France because legal environment remains definitely less risky than in United States for the civil liability for auditor. The French civil code imposes, indeed, formalism heavier than principles of Common Law and strongly reduces judges' capacity of interpretation. 
Francis (2004) also studied how the legal system of a country affects the behaviour of auditor through the care of auditor to satisfy his responsibility for juridical audit. In other terms, the incentives of auditors are affected by potential legal responsibility and any other sanction which relates to negligence and bad conduct. In the same way, Francis and Wang (2004) show that audit firms pertaining to Big 4 treat their customers in a more preserving way in countries having a legal system which gives investors a great protection, than in particular countries of Common Law including capacity to continue auditors. This leads us to pose the first hypothesis:

H1: The companies belonging to countries with strong legal protection system of outsiders will be more likely to have a higher audit quality than companies belonging to countries with weak legal protection system.

\section{Audit Quality and Investment Opportunity Set}

Investment opportunities are growth options that can either be taken or not at the managers' discretion (Myers, 1977). They represent future investments whose value is uncertain because it depends on discretionary expenses made by the managers. Hence, the managers are likely to have more information about investment opportunities and their value than the shareholders (Bizjak et al., 1993). Furthermore, the management of investment opportunities requires decision-making in uncertain environment. Consequently managerial action is more unobservable (Smith \& Watts, 1992). Compared with managers of low investment opportunity firms, those of high investment opportunity firms are more likely to manage earnings (Skinner, 1993). Thus, shareholders of high investment opportunity firms have a greater need of monitoring their managers.

Unlike low investment opportunity firms, high investment opportunity firms are less likely to have the control benefit of debt or capital market monitoring. Debt payment reduces the resources under the managers' control, but high investment opportunity firms are less likely to have high debt because of the asset substitution problem or the under-investment problem (Myers, 1977; Smith \& Warner, 1979).

Auditing is an important means of monitoring the managers long before the requirement of the law (Watts \& Zimmerman, 1983). Independent auditors will report detected material mis-statements in audited financial statements. However, the likelihood of detecting and reporting mis-statements depends on the expected loss of the auditors in case of audit failure. The auditing literature suggests that Big 4 auditors will suffer a greater loss in terms of reputation or quasi-rent in case of audit failure (Li, 2004; He, Piot, Labelle, \& Thoronton, 2006). Big 4 auditors are more likely to provide a higher quality audit than non-Big 4 auditors because they have a higher likelihood of reporting detected mis-statements.

In a firm with high investment opportunity set, legal auditor can be solicited for his knowledge in the branch of industry, but particularly for his independence from the arbitration of countable choices of direction. For example, choices of both spreading out countable of certain expenditure (like expenses of qualification of new lines of production) and inscription in active of expenses of R\&D can bring conflict situations. In such situations, the auditor must arbitrate in all independence to put forth an objective judgement on the treatment considered in comparison with the principles of regularity, sincerity and faithful image of financial statements. In addition, if investment opportunity set represents a high share of the firm's value, then the latter presents more risks and uncertainties. The reason for such uncertainties and risks is exclusively made up by its credits in place. Consequently, the need to reassure shareholders in place and investors potential can appear by the choice of a legal auditor with high reputation, whose certification constitutes a signal of published quality information. In short, high investment opportunity set can influence policy of company control. According to the audit quality, 
this should appear by the will to present audited financial statements by international wide-area networks, mainly for better controlling asymmetry of information which weighs on the firm's situation (objectives), and conveys a signal of financial information quality disseminated with investors. From here it lies our second hypothesis:

H2: The companies having high investment opportunity set will be more likely to have a higher audit quality than companies having low investment opportunity set.

\section{Audit Quality and Ownership Structure}

Ownership structure is a key determinant of corporate governance (Sheifer \& Vishny, 1997; La Porta et al., 1998, 2000; Gul, Kim, \& Qiu, 2010). The theory of agency recognizes audit as one of the principal mechanisms of management conflicts and reduction of agency costs. Consequently, a modification in intensity of agency conflicts should influence, in same direction, acceptable level on audit quality. The relations between external and leader shareholders are marked by problems of moral risk and opportunism, which depend on the level of asymmetry of information. The two parts may find it beneficial to minimize asymmetry of information: Owners develop their investment by a better control of the firm richness, by accepting a more effective controlling authority considered. Leaders can announce quality of their management and increase their remuneration. In both cases, a reinforcement of audit quality can reduce asymmetry of information.

According to Jensen and Meckling (1976), divergences of interests and opportunist behaviours are conversely related to ownership structure, therefore, with degree of separation property-management. Moreover, asymmetry of information is overall reduced if people, having one access to privileged information-leaders and administrators, hold a significant share of capital. In addition, Francis and Wilson (1988) specify that dispersed ownership structure increases, for external shareholders, the cost and efforts are necessary to influence decisions of leaders, and in particular to impose a change of brains trust. The pressure of shareholders on leaders is thus less if ownership structure is dispersed.

Fama and Jensen (1983a, 1983b) explain the survival and the performance of large companies, which are exposed to problems of agency by the diffusion of their shareholding, nature of rights of ownership and hierarchical organization of decision-making process. Initially, limited responsibility and free transferability of actions state that a minority shareholder may not find it beneficial to invest himself directly in control of decisions of leaders. In second time, Fama and Jensen explain why the separation of management and control decisions constitutes a condition necessary to efficient operation of open companies. Thus, board of directors plays a role in the system of control to ratify strategic decisions and then evaluates their results. Shareholders preserve prerogative to designate legal auditor in general assembly. This last has the widest capacities as regards access to information to achieve its mission and to protect interests from its Mandan's. Consequently, audit quality can be regarded as one of the components of a system of control complexes in charge of compensating for relative incapacity of a shareholding dispersed structure meant to supervise and control countable policy of leaders. Conversely, in controlled companies, majority shareholders reach directly privileged information and replace board of directors to appreciate decisions of leaders (Pochet, 1998). In this case, the role of auditor consists in defending interests of minority shareholders.

Thus, the role of audit consists in defending interests of minority shareholders and reducing conflicts of agency which exist between majority shareholders and leaders. Indeed, audit quality can be regarded as one of the components of a system of control complexes in charge of compensating for relative incapacity of diffusion of 
property to supervise and control countable decisions of leaders. In this direction, audit quality seems to be more significant in companies having a dispersed structure of shareholding. From here it lies our third hypothesis:

H3: The companies having a dispersed structure of shareholding will be more likely to have a higher audit quality than companies having a concentrated structure of shareholding.

\section{Measurement of Variables}

\section{Measurement of Audit Quality}

To measure our dependant variable audit quality, we need to estimate the membership of the group of ten international wide-area networks in term of sales turnover. This dichotomy allows a homogeneous international comparison, while remaining most widespread and least debatable according to authors and experts. The international wide-area networks, indeed, are recognized for their capital of specific reputation (high investments in recruitment, internal formation, methods and techniques of work). Thus, audit quality is the subject of a binary variable: $\mathrm{AQ}$ is coded 1 if companies make recourse to ten international wide-area networks of audit in term of sales turnovers. Otherwise AQ is coded 0.

\section{Measuement of Legal System}

Legal system is measured starting from three variables like La Porta et al. $(1997,1998,2004)$ and Deffains, Boughanmi and Ibourk (2005).

Legal origin. Identifies the legal origin of the company law or commercial code of each country. Equals 1 if the origin is Civil Law and equals 0 if the origin is Common Law.

Contents of legal rules. Measured starting from two indicators in particular protection of rights of minority shareholders and protection of rights of creditors.

(1) Protection of rights of minority shareholders: measured by indices estimating quality of protection of minority shareholders:

The indicator "One shares one vote" SharVote: Equals 1 if the Company Law or Commercial Code of the country requires that ordinary shares carry one vote per share, and 0 otherwise. Equivalently, this variable equals 1 when the law prohibits the existence of both multiple-voting and non-voting ordinary shares and does not allow firms to set a maximum number of votes per shareholder irrespective of the number of shares she owns, and 0 otherwise.

An index aggregates the shareholder rights which we labelled as "anti-director rights". The index is formed by adding 1 when: (a) The country allows shareholders to mail their proxy vote to the firm; (b) Shareholders are not required to deposit their shares prior to the General Shareholders' Meeting; (c) Cumulative voting or proportional representation of minorities in the board of directors is allowed; (d) An oppressed minorities mechanism is in place; (e) The minimum percentage of share capital that entitles a shareholder to call for an Extraordinary Shareholders' Meeting is less than or equal to 10 percent (the sample median); or (f) Shareholders have pre-emptive rights that can only be waved by a shareholders' vote. The index ranges from 0 to 6 .

(2) Protection of rights of creditors is estimated by using an index aggregating different creditor rights “CreRight”. The index is formed by adding 1 when: (a) The country imposes restrictions, such as creditors' consent or minimum dividends to file for reorganization; (b) Secured creditors are able to gain possession of their security once the reorganization petition has been approved (no automatic stay); (c) Secured creditors are ranked first in the distribution of the proceeds that result from the disposition of the assets of a bankrupt firm; and (d) The 
debtor does not retain the administration of its property pending the resolution of the reorganization. The index ranges from 0 to 4 .

Quality of application of legal rules. It is estimated via 5 measurements extracted from the research of La Porta et al. $(1998,2004)$ :

(1) Efficiency of judicial system (EJS): Assessment of the "efficiency and integrity of the legal environment as it affects business, particularly foreign firms" produced by the country-risk rating agency Business International Corporation. It "may be taken to represent investors' assessments of conditions in the country in question”. Scale from 0 to 10, with lower scores for lower efficiency levels;

(2) Rule of law (RL): Assessment of the law and order tradition in the country produced by the country-risk rating agency international country risk. Scale from 0 to 10 , with lower scores for less tradition for law and order (we changed the scale from its original range going from 0 to 6 );

(3) Corruption (C): International country risk's assessment of the corruption in government. Lower scores indicate "high government officials are likely to demand special payments" and "illegal payments are generally expected throughout lower levels of government" in the form of "bribes connected with import and export licenses, exchange controls, tax assessment, policy protection, or loans”. Scale from 0 to 10 , with lower scores for higher levels of corruption;

(4) Risk of expropriation (RE): International country risk's assessment of the risk of "outright confiscation" or "forced nationalization”. Scale from 0 to Guide 10, with lower scores for higher risks;

(5) Repudiation of contracts by government (RCR): International country risk's assessment of the "risk of a modification in a contract taking the form of repudiation, postponement, or scaling down" due to "budget cutbacks, indigenization pressure, a change in government, or a change in government economic and social priorities”. Scale from 0 to 10, with lower scores for higher risks.

\section{Measurement of Investment Opportunity Set}

This variable can be measured by two ratios:

- Market to book value equity: The ratio of market value of equity to book value of equity at the end of the fiscal year, like Gaver and Gaver (1993), Bah and Dumontier (1998);

- Market to book value assets: The ratio of market value of assets to book value of total net assets at the end of the fiscal year, like Lang and Litzenberger (1989) and Dierkens (1991).

\section{Measurement of Ownership Structure}

This variable is a dichotomy measurement taking the value of 1 if percentage of capital held by the first three shareholders is equal to or higher than $30 \%$ and 0 if not. This measurement is used like Dhaliwal et al. (1981) and Chopard (2003).

\section{Measure of Variables' Control}

(1) Size of audited company: It is certain that audit firm of regional audit do not have the scale, in particular in human means, to accept audit quality of a multinational. Thus, for obvious constraints related to the function of offer of service (availability of average materials and human), only audit firm of certain size are in measurement of large companies.

In this paper, we chose to study nature of audit quality in the 25 larger companies, in term of each country, 
sales turnover. Thus, we await a positive correlation between size of audit firm and size of audited company. This variable is usually measured by natural logarithm of total assets like Godfrey and Hamilton (2005).

(2) International presence of company: A strongly committed company, having many operational centres out of the borders, will be more effectively audited by a large firm integrated in a solid international network due to two reasons. On the one hand, there is a more extended recognition of signature of audit and a better control of constraints of geographical dispersion, with a particular presence of correspondents specialized in local legislations and be able to pay visits on site at lower cost (Piot et al., 2006). We consider, thus, measurement "export" to appreciate international presence which represents proportion of sales turnover realized out of country of origin.

(3) Debt: The conflicts between shareholders and creditors are in general easily controllable from contractual character of financing by debt (Jensen \& Meckling, 1976). Moreover, French companies privilege, culturally, banking debt with issues of bonds. In United States, issues of bonds are often matched restrictive clauses in order to control conflicts between bond-holders and shareholders. The respect of these clauses, frequently centred on countable figures, is attested each year by auditor.

The debt thus constitutes an explicit mechanism of control of costs of agency of free cash-flow, and more generally of conflicts between owners and managers (Piot, 2003). Consequently, if a debt makes it possible to discipline leaders, and thus to control conflicts with shareholders, requirements of latter towards auditor could prove less significant. For this reason, we rather consider debt as a parameter of control of costs of agency between shareholders and leaders, through measurement of long-term debts compared to total assets (DLT/TA). This ratio is used like Chen et al. (2005) and Godfrey and Hamilton (2005).

\section{Sample}

\section{Sample and Data Sources}

Our sample period covers the six-year period, 2000-2005. We extract data from “Orbis 2006” database and legal data were extracted from appendices of work of La Porta et al. (1997, 1998, 2004) and Deffains et al. (2005).

In this paper, we choose to study three countries particularly, United States, France and Germany, which pertain to three legal systems.

\section{Empirical Models for Hypothesis Testing}

To test the relation between audit quality and legal systems, investment opportunity set and ownership concentration, we estimate the following regression:

$$
\begin{gathered}
A Q_{k t}=\beta_{0}+\beta_{1} \text { Origin }_{k t}+\beta_{2} \text { IOS }+\beta_{3} \text { Ownership Struc }+\varepsilon_{k t} ; \\
A Q_{k t}=\beta_{0}+\beta_{1} \text { CreRight }_{k t}+\beta_{2} \text { AntDight }_{k t}+\beta_{3} \text { SharVote }_{k t}+\beta_{4} \text { IOS }+\beta_{5} \text { Ownership Struc } \varepsilon_{k t} ; \\
A Q_{k t}=\beta_{0}+\beta_{1} \text { EJS }_{k t}+\beta_{2} R L_{k t}+\beta_{3} C_{k t}+\beta_{4} R E_{k t}+\beta_{4} R C R_{k t}+\beta_{5} \text { IOS }+\beta_{6} \text { Ownership Struc }+\varepsilon_{k t} .
\end{gathered}
$$

where:

$A Q=$ Audit quality;

Ownership Struc = Ownership structure;

IOS = Investment opportunity set;

Origin = Origin of legal system;

CreRight $=$ Creditor rights, this index measures the rights of creditors; 
AntDRight $=$ Anti director rights, this index measures the rights of minority shareholders;

ShareVote $=$ This index measures the rights of minority shareholders;

EJS = Efficiency of judicial system;

$R L=$ Legal rules;

$C$ = Degree of corruption;

$R E=$ Risk of expropriation;

$R C R=$ Likelihood of contract repudiation by government.

\section{Results of Logistic Regression}

The multivariate analysis makes it possible to appreciate marginal contribution of various variables, in particular of interactive variables, on audit quality. Table 1 summarizes statistical results obtained for three countries, especially, United States, France and Germany.

The first model takes again the first measurement of legal system relating to legal origin of country. The second is interested in contents of application of legal rules and the last model relates to quality of application of these legal rules.

The test of khi-deux is for the adjustment of empirical models to a value of 89.725, 93.75 and 104.21 respectively for three models (6 degrees of freedom) and is significant to 0.000 making it possible to reject null hypothesis stipulating that all coefficients are equal to zero. This resulted in retaining $\mathrm{H} 1$ according to which at least one of explanatory variables is significant. The checking of force of association of these models also makes it possible to have respectively $R^{2}$ of Nagelkerke which amounts to $0.65,0.74$ and 0.77 which is considered to be satisfactory taking into account the exploratory character of model. Thus, the model explains $65.3 \%$ respectively, $74 \%$ and $77.8 \%$ of variance of variable to be explained, in our case size of audit firm.

The hypothesis H1, revealing that companies belonging to countries with strong legal protection system of outsiders choose audit firm pertaining to the ten international wide-area networks, is in conformity with theoretical predictions. Moreover, models relating at origin, quality and contents of application of legal rules prove statistically significant. This supposes that there is a significant relation between choice of audit firm and legal system of country. This result corroborates the remarks of La Porta et al. (1998 to 2004) announcing that there is a high relation between legal levels of protection of investors, in particular in choice of audit firm and legal tradition of country.

The hypothesis H2, stipulating that companies having high investment opportunity set tend to resort to audit firm pertaining to the ten international wide-area networks, proves non conformity with theoretical predictions for three models. Indeed, results of investment opportunity set (MBVE \& MBVA) present a non significant relation concerning choice of audit firm. This result can be explained, on the one hand, by opportunist behaviour of leaders within a company (moreover, investment opportunity set is evaluated on the basis of discretionary decision of investments future of leaders). On the other hand, leaders will privilege their interest to the detriment of policy of control and monitoring in particular the choice of audit firm, which makes it possible to cancel the relation which exists between choice of audit firm and investment opportunity set. However, the found results contradict the research of Piot (2004), Wah (2002) and Hutchinson (2001) announcing that companies having a high investment opportunity set can influence their policy of control. 
Table 1

Results of Logistic Regressions of Audit Quality

\begin{tabular}{|c|c|c|c|}
\hline Variables (awaited correlation) & Model 1 & Model 2 & Model 3 \\
\hline Constant & $\begin{array}{l}24.38 * * * \\
(0.002)\end{array}$ & $\begin{array}{l}14.43 \\
(0.314)\end{array}$ & $\begin{array}{c}-113.76^{* * * *} \\
(0.000)\end{array}$ \\
\hline Legal origin $(+)$ & $\begin{array}{l}1.57^{*} \\
(0.09)\end{array}$ & & \\
\hline $\operatorname{MBVE}(+)$ & $\begin{array}{l}-0.322 \\
(0.293)\end{array}$ & $\begin{array}{c}0.307 \\
(0.521)\end{array}$ & $\begin{array}{l}-0.161 \\
(0.737)\end{array}$ \\
\hline $\operatorname{MBVA}(+)$ & $\begin{array}{l}-0.78 \\
(0.225)\end{array}$ & $\begin{array}{l}-1.181 \\
(0.257)\end{array}$ & $\begin{array}{c}0.269 \\
(0.741)\end{array}$ \\
\hline Ownership struc. (-) & $\begin{array}{r}226.53 * * \\
(0.025)\end{array}$ & $\begin{array}{c}454.477^{* *} \\
(0.019)\end{array}$ & $\begin{array}{r}300.572 * \\
(0.061)\end{array}$ \\
\hline $\log \mathrm{TA}(+)$ & $\begin{array}{l}3.567 * * * \\
(0.000)\end{array}$ & $\begin{array}{l}3.79 * \\
(0.058)\end{array}$ & $\begin{array}{c}0.439 \\
(0.600)\end{array}$ \\
\hline Export $(+)$ & $\begin{array}{l}3.231^{* *} \\
(0.025)\end{array}$ & $\begin{array}{c}-17.80^{* * *} \\
(0.000)\end{array}$ & $\begin{array}{c}-22.66 * * * \\
(0.000)\end{array}$ \\
\hline DLT/TA (-) & $\begin{array}{l}-5.671 * * \\
(0.027)\end{array}$ & $\begin{array}{c}-10.24 * * \\
(0.019)\end{array}$ & $\begin{array}{l}-7.010^{*} \\
(0.061)\end{array}$ \\
\hline Creditor right $(+)$ & & $\begin{array}{l}6.43 * * * \\
(0.000)\end{array}$ & \\
\hline Anti director right $(+)$ & & $\begin{array}{l}4.867 * * * \\
(0.000)\end{array}$ & \\
\hline Share vote $(+)$ & & $\begin{array}{c}4.9 * * \\
(0.014)\end{array}$ & \\
\hline EJS $(+)$ & & & $\begin{array}{l}-4.25^{* *} \\
(0.006)\end{array}$ \\
\hline $\mathrm{RL}(+)$ & & & $\begin{array}{l}71.340 * * * \\
(0.000)\end{array}$ \\
\hline $\mathrm{C}(+)$ & & & $\begin{array}{l}54.670^{* * * *} \\
(0.000)\end{array}$ \\
\hline RE (-) & & & $\begin{array}{c}-586.213 * * * \\
(0.000)\end{array}$ \\
\hline RCR (-) & & & $\begin{array}{l}-0.91^{*} \\
(0.08)\end{array}$ \\
\hline -2 Log likelihood & 159.763 & 154.083 & 164.246 \\
\hline Chi-deux & $89.725^{* * *}$ & $93.75^{* * *}$ & $104.21 * * *$ \\
\hline$R^{2}$ of nagelkerke (\%) & 65.3 & 74 & 77.8 \\
\hline Goods of arrangement (\%) & 87.6 & 91 & 94.5 \\
\hline
\end{tabular}

Notes. * Significant with a threshold of $10 \%$; ** Significant to a threshold of $5 \%$; ** Significant to a threshold of $1 \%$.

Contrary to H3 hypothesis, it appears that companies having a dispersed ownership structure do not have a high audit quality while resorting to audit firm not belonging to ten international wide-area networks. Indeed, statistical results reveal a positive sign and a statistically significant coefficient with the threshold of 5\%, 5\% and $10 \%$ respectively for three models. Though this hypothesis is not in conformity with theoretical predictions, such results can be aligned with empirical results of Piot (2001). The authors explain this relation by inadequacy of theory of agency, initially founded in an Anglo-Saxon context, with French context of his study characterized by a high concentration of property.

Concerning variables' control, empirical results show that size of audited company is significant with a threshold of $1 \%$ and $10 \%$ only for the first two models, after transformation logarithmic curve of active total, operation makes it possible to correct high asymmetry in initial distribution of this variable. For international presence, it proves that audited companies by audit firm belonging to the ten international wide-area networks 
appear more turned much towards international one with level of the sales actual abroad for the three studied models. This result consolidates international recognition of international wide-area networks and their extents in the world. This result is probably explained by strategy of internationalization adopted by these companies implying the establishment of various subsidiary companies throughout the world. Indeed, majority of companies composing the sample have several subsidiary companies abroad. In the same way, the importance of sales turnover realized out of country of origin can explain the recourse of companies to international wide-area networks. In fact, the sales turnover to export of companies belonging to various countries varies between $40 \%$ and $60 \%$. Lastly, and in accordance with our waiting, it proves that debt constitutes a parameter of control of costs of agency between shareholders and leaders. Indeed, this variable of control is statistically significant for the three models.

\section{Robustness Checks}

Predictive capacity of logistic model multivariate makes it possible to test determinants of audit quality by using 425 observations for the first and the third model and 400 observations for second model. The results of this test are satisfactory. Indeed, total rate of correct classification rises from $87.6 \%$ for first model up to $94.5 \%$ for third model and, consequently, error rate decreases from $11.11 \%$ to $5.05 \%$. Thus, in a respective way, models predict 385 correctly; 373 and 407 companies using audit firm pertain to the ten international wide-area networks.

\section{Summary and Concluding Remarks}

In this paper, the logistic regression analyses give interesting results when audit quality is appreciated by the size of audit firm, in particular the membership to the ten international wide-area networks. The principal results relating to the choice of audit firm pertaining to the ten international wide-area networks of audit show that specificity of legal system in particular, origin, contents and quality of application of legal rules are positively associated with audit quality. These results support the studies of La Porta et al. (1998 to 2004) putting forward importance from the impact from legal system on mechanisms from government's company. The audit quality constitutes, in fact, one of these external mechanisms.

Concerning the level of investment opportunity set, this variable seems to partially influence audit quality, appreciated by size of audit firm. This impartiality is due probably to the measurement of investment opportunity set adopted within the framework of this research task (stock exchange capitalization of stockholders' equity versus stock exchange capitalization of credits). Thus and since such a result could be sensitive to measurements chosen, it would be more judicious to resort to the other measurements envisaged by countable literature (e.g., financial risk or $\mathrm{Q}$ of Tobin) to ensure the validity of results apart from measurements used.

In addition, a structure of dispersed shareholding, observed in companies of various countries chosen, does not explain the recourse of these companies in search of a high audit quality. This situation contradicts perfectlytheoretical predictions though it comes in support of some empirical notes following Piot (2001).

\section{References}

Adam, T., \& Goyal, V. K. (2003). The investment opportunity set and its proxy variables: Theory and evidence. Hong Kong University of Science \& Technology, working paper.

Chow, C. (1982). The demand for external auditing: Size, debt and ownership influences. The Accounting Review, 57(2), $272-291$. Deangelo, L. E. (1981). Auditor size and audit quality. Journal of Accounting \& Economics, 183-199. 
Deffains, B., Boughanmi, A., \& Ibourk, A. (2005). Analyse économétrique des réformes de gouvernance d'entreprise et de la structure du système financier en France entre 1980 et 2004. Université Nancy 2, working paper.

Fama, E. F., \& Jensen, M. C. (1983a). Separation of ownership and control. Journal of Accounting \& Economics, 26, $301-325$.

Fama, E. F., \& Jensen, M. C. (1983b). Agency problems and residual claims. Journal of Accounting \& Economics, $26,327-349$.

Francis, J. R. (2004). What do we know about audit quality. The British Accounting Review, 36, 345-368.

Francis, J. R., \& Wang, D. (2004). Investor protection and auditor conservatism: Are Big 4 auditors conservative only in the United States? University of Missouri and University of Nebraska, Working paper.

Francis, J. R., Khurana, I. K., \& Pereira, R. (2001). Investor protection law, accounting and auditing around the world. University of Missouri-Columbia, working paper, 1-38.

Francis, J. R., Khurana, I. K., \& Pereira, R. (2003). The role of accounting and auditing in corporate governance, and the development of financial markets around the world. Asia-Pacific Journal of Accounting and Economics, 10(1), 1-30.

Francis, J. R., Maydew, E. L., \& Sparks, H. C. (1999). The role of Big Six auditors in the credible reporting of accruals. Auditing, Sarasota, 1-14.

Gaver, J. J., \& Gaver, K. M. (1993). Additional evidence on the association between the investment opportunity set and corporate financing, dividend and compensation policies. Journal of Accounting \& Economics, 16, 125-160.

Godfrey, J. M., \& Hamilton, J. (2005). The impact of R\&D intensity on demand for specialist auditor services. Contemporary Accounting Research, 22(1), 55-93.

Grand, B. (1996). Approches théoriques de l'audit. Centre d'Etudes et de Recherches sur les Organisations et la Gestion, IAE Aix-en-Provence, Université Aix Marseille III, working paper.

Gul, F. A., Kim, J. B., \& Qiu, A. A. (2010). Ownership concentration, foreign shareholding, audit quality, and stock price synchronicity: Evidence from China. Journal of Financial Economics, 95, 425-442.

He, L., Piot, C., Labelle, R., \& Thoronton, D. B. (2006). Board monitoring, audit quality, and financial reporting quality: A review of empirical evidence. Chaire en gouvernance et juricomptabilité d’HEC Montréal, working paper, 1-61.

Jensen, M. C., \& Meckling, W. (1976). Theory of the firm: Managerial behaviour, agency costs and ownership structure. Journal of Financial Economics, 3(4), 305-360.

La Porta, R. F., Lopez-De-Silanes, \& Shleifer, A. (1999). Corporate ownership around the world. Journal of Finance, 54, 471-517.

La Porta, R. F., Lopez-De-Silanes, Shleifer, A., \& Vishny, R. (1997). Legal determinants of external finance. Journal of Finance, 52, 1131-1150.

La Porta, R. F., Lopez-De-Silanes, Shleifer, A., \& Vishny, R. (1998). Law and finance. Journal of Political Economy, 106, 1113-1155.

La Porta, R. F., Lopez-De-Silanes, Shleifer, A., \& Vishny, R. (2000a). Agency problems and dividend policies around the world. Journal of Finance, 55, 1-33.

La Porta, R. F., Lopez-De-Silanes, Shleifer, A., \& Vishny, R. (2000b). Investor protection and corporate governance. Journal of Financial Economics, 58, 3-27.

Lefebvre, F. (2006). Mémento pratique: Audit et commissariat aux comptes 2007-2008. Editions Francis Lefebvre, 1-1320.

Manita, R., \& Chemingui, M. (2007). Les approches d'évaluation et les indicateurs de mesure de la qualité d'audit: Une revue critique, working paper.

Piot, C. (2001). Agency costs and audit quality: Evidence from France. The European Accounting Review, 10(3), 461-499.

Piot, C. (2004). The existence and independence of audit committees in France. Accounting and Business Research, 34(3), $223-246$.

Wah, L. K. (2002). Investment opportunity and audit quality. City University of Hong Kong, working paper. 